\title{
Perbandingan NIHSS pada pasien stroke hemoragik dan non-hemoragik yang rawat inap di Bagian Neurologi RSUP Prof. Dr. R. D. Kandou Manado
}

\author{
${ }^{1}$ Habir Jojang, \\ ${ }^{2}$ Theresia Runtuwene \\ ${ }^{2}$ J. Maja. P.S
}

\author{
${ }^{1}$ Kandidat Skripsi Fakultas Kedokteran Universitas Sam Ratulangi \\ ${ }^{2}$ Bagian Neurologi Fakultas Kedokteran Universitas Sam Ratulangi \\ Email: habirjojang@gmail.com
}

\begin{abstract}
Stroke is a syndrom identified with fast growing symptoms and clinical signs in the form of focal or global disturbance of brain function in more than 24 hours. The clinical signs are carotid blood vessel disturbance (including disturbance of sensation ability on face and mouth, hemiparesis/hemiplegia, and unconsciousness); and vertebrobasilaris blood vessel disturbance (including lack of balance, vertigo, hypotonia on both legs, and swallowing and vomitting problems). National Institute of Health Stroke Scale is a systematic assessment tool that measures the quantity of stroke related to neurological deficit by using 15 assessment items. This study aimed to find out the comparison of neurological deficit between hemorrhagic and nonhemorrhagic stroke inpatients at the Neurology Department of Prof. Dr. R.D. Kandou Hospital Manado. The results showed that mild neurological deficit was found in $38.9 \%$ of hemorrhagic stroke patients and in $11.8 \%$ of non-hemorhagic stroke patients. Moderate neurological deficit was found found in $33.3 \%$ of hemorrhagic stroke patients and $35.3 \%$ of non-hemorhagic stroke patients. Meanwhile, neurological deficit was found in $27.8 \%$ of hemorrhagic stroke patients and $52.9 \%$ of non-hemorhagic stroke patients. Conclusion: NIHSS of mild neurological deficit in hemorrhagic stroke patients was higher than in non-hemorrhagic stroke patients, meanwhile, of moderate deficit both groups were the same, and of severe neurological deficit the NIHSS was higher in non-hemorrhagic stroke patients.
\end{abstract}

Keywords: NIHSS, stroke, hemorrhagic stroke, non-hemorrhagic stroke.

\begin{abstract}
Abstrak: Stroke adalah suatu sindrom yang ditandai dengan gejala atau tanda klinis yang berkembang cepat berupa gangguan fungsional otak fokal maupun global yang berlangsung lebih dari 24 jam. Pada stroke terdapat gejala klinis terdiri dari gangguan pembuluh darah karotis yaitu gangguan rasa di daerah muka, mulut, hemiparesis/hemiplegi, dan tidak sadar. Gangguan pembuluh darah vertebrobasilaris yaitu kehilangan keseimbangan, vertigo, kedua kaki hipotoni, gangguan menelan, dan muntah. National Institute of Health Stroke Scale adalah alat penilaian sistematik yang mengukur kuantitatif stroke yang terkait dengan defisit neurologik, terdiri dari 15 item pemeriksaan. Penelitian ini bertujuan untuk mengetahui perbandingan defisit neurologik antara stroke hemoragik dan non hemoragik pada pasien yang dirawat inap di bagian Neurologi RSUP Prof. Dr. R.D Kandou Manado. Jenis penelitian ini deskriptif prospektif. Subjek penelitian yaitu pasien yang menderita stroke di bangsal Neurologi RSUP Prof Dr. R.D Kandou Manado periode Januari 2013. Hasil penelitian menunjukan bahwa defisit neurologis ringan pada stroke hemoragik sebesar 38,9\% dan pada stroke non hemoragik sebesar 11,8\%; defisit neurologis sedang pada stroke hemoragik sebesar 33,3\% dan pada stroke non hemoragik sebesar 35,3\%; defisit neurologis berat pada stroke hemoragik sebesar $27,8 \%$ dan pada stroke non-hemoragik sebesar 52,9\%. Simpulan: Pemeriksaan NIHSS untuk derajat neurologis ringan penderita stroke hemoragik lebih banyak daripada penderita stroke non hemoragik; untuk derajat neurologis sedang sama banyak dan untuk derajat neurologis berat penderita stroke non hemoragik lebih banyak.
\end{abstract}

Kata kunci: NIHSS, stroke, stroke hemoragik, stroke non hemoragik 
Pada stroke gejala atau tanda klinis berkembang dengan cepat berupa gangguan fungsional otak fokal maupun global yang berlangsung lebih dari 24 jam. ${ }^{1}$ Stroke adalah sindrom klinis yang ditandai dengan serangan defisit sebagian atau keseluruhan yang disebabkan oleh gangguan pembuluh darah pada otak. Stroke merupakan kegawat daruratan neurologi karena timbul mendadak dan dapat menyebabkan kematian. $^{2}$

Menurut data Center for Disease Control (CDC) stroke merupakan penyebab kematian terbanyak ketiga setelah penyakit jantung dan keganasan. ${ }^{2}$ Menurut WHO tahun 2002, lebih dari 5,47 juta orang meninggal karena stroke di dunia. Dari data yang dikumpulkan oleh American Heart Association tahun 2004 setiap tiga menit satu orang meninggal akibat stroke., Stroke di Indonesia diperkirakan mencapai 500.000 kasus per tahun. Sekitar 25\% penderita stroke tersebut meninggal dunia dan sisanya mengalami cacat ringan atau berat. $^{2}$

Klasifikasi stroke dibagi menjadi dua yaitu, stroke perdarahan dan stroke iskemik. Stroke iskemik merupakan penyebab sebagian besar kasus stroke sekitar 85\% dan stroke perdarahan hanya sekitar 15\%. Stroke iskemik bisa disebabkan oleh lesi trombotik akibat aterosklerosis di jantung atau pembuluh darah arteri otak, sedangkan stroke perdarahan disebabkan oleh pecahnya pembuluh darah otak, baik intrakranial maupun subaraknoid. ${ }^{2,4,5}$

Pada stroke terdapat gejala klinis yang terdiri dari gejala pada gangguan pembuluh darah karotis yaitu gangguan rasa di daerah muka/wajah sesisi, mulut, perut, hemiparesis/hemiplegi, tidak sadar, atau merasa anggota badan sesisi tak ada. Gangguan pada pembuluh darah vertebrobasilaris yaitu kehilangan keseimbangan, vertigo, kedua kaki hipotoni/lemah, tidak dapat berdiri, gangguan menelan, dan muntah. $^{6}$

National Institute of Health Stroke Scale (NIHSS) adalah alat penilaian sistematis yang mengukur kuantitatif stroke yang terkait dengan defisit neurologik. NIHSS tidak hanya digunakan untuk menilai derajat defisit neurologik saja, tetapi juga untuk memfasilitasi komunikasi antara pasien dengan tenaga medik, mengevaluasi, menentukan perawatan yang tepat dan memrediksi hasil dari pasien stroke, menentukan prognosis awal dan komplikasi serta intervensi yang diperlukan. $^{7.8}$ NIHSS juga banyak digunakan untuk menilai tingkat keparahan pada pasien yang mengalami stroke iskemik akut. Pada saat ini NIHSS banyak digunakan secara rutin untuk menilai keparahan stroke pada pusat-pusat pelayanan stroke. ${ }^{9}$

Terdapat 11 item dalam penilaian NIHSS meliputi: level of consciousness, best gaze, visual field testing, facial paresis, arm and leg motor function, limb ataxia, sensory, language, dysarthria, extinction, and inattention. NIHSS memiliki skor maksimum 42 dan skor minimum 0. Interpretasi dari NIHSS yaitu: skor $>25$ sangat berat, $14-25$ berat, 5-14 sedang, dan $<5$ ringan. $^{7}$

\section{METODE PENELITIAN}

Jenis penelitian ini deskriptif prospektif. Penelitian ini dilakukan pada bulan Januari 2013 di bangsal Neurologi RSUP Prof Dr. R.D Kandou Manado Subjek penelitian yaitu pasien yang menderita stroke di bangsal Neurologi RSUP Prof Dr. R.D Kandou Manado periode Januari 2013.

Dalam penelitian ini digunakan National Institute of Health Stroke Scale (NIHSS) dan informed consent.

\section{HASIL PENELITIAN}

Hasil penelitian menunjukan bahwa defisit neurologis ringan pada stroke hemoragik sebesar 38,9\% dan pada stroke non hemoragik sebesar 11,8\%, defisit neurologis sedang pada stroke hemoragik sebesar 33,3\% dan pada stroke non hemoragik sebesar 35,3\%, defisit neurologis berat pada stroke hemoragik sebesar $27,8 \%$ dan pada stroke nonhemoragik sebesar 52,9\%. 
Tabel 1. Perbandingan Nilai NIHSS pada Stroke Hemoragik dan Stroke Non-Hemoragik

\begin{tabular}{ccccc}
\hline Defisit Neurologik & $\begin{array}{c}\text { Stroke } \\
\text { Hemoragik }\end{array}$ & $\%$ & $\begin{array}{c}\text { Stroke Non- } \\
\text { Hemoragik }\end{array}$ & $\%$ \\
\hline Ringan $(<5)$ & & & & \\
Sedang (5-14) & 7 & 38,9 & 2 & 11,8 \\
Berat (15-25) & 6 & 33,3 & 6 & 35,3 \\
Sangat Berat $(>25)$ & - & 27,8 & 9 & 52,9 \\
Total & 18 & - & - & - \\
\hline
\end{tabular}

\section{BAHASAN}

Berdasarkan hasil penelitian yang dilakukan di bangsal bagian Neurologi RSUP Prof. Dr. R.D. Kandou Manado selama periode bulan Januari 2013 didapatkan sejumlah 35 subyek penelitian yang dibagi atas dua kelompok yaitu: penderita stroke hemoragik $(48,5 \%)$ dan penderita stroke non-hemoragik (51,5\%).

Hasil penelitan menunjukkan bahwa defisit neurologik ringan pada stroke hemoragik sebesar 38,9 \% dan pada stroke non-hemoragik sebesar 11,2\%; defisit neurologik sedang pada stroke hemoragik sebesar 33,3\% dan pada stroke non hemoragik sebesar 35,3\%; dan defisit neurologik berat pada stroke hemoragik sebesar $27,8 \%$ dan pada stroke nonhemoragik sebesar 52,9\%.

Hasil penelitian ini serupa dengan penelitian yang dilakukan oleh Siswonoto di bangsal rawat inap UPF Penyakit saraf RSUPP Dr Kariadi Semarang yang melaporkan sebanyak 32,6\% penderita stroke non-hemoragik dengan defisit neurologik ringan, sedangkan sebanyak $67,4 \%$ menderita defisit neurologik ringansedang, dan sebanyak $51,2 \%$ penderita menderita defisit neurologik sedang-berat. ${ }^{8}$

Hasil yang berbeda didapatkan pada penelitian yang dilakukan oleh Davar di Neurology Department of Alavi Hospital, Ardebi. Dari 100 pasien stroke nonhemoragik didapatkan defisit neurologik derajat sangat berat (NIHSS $>25$ ) pada dua pasien, sedangkan dari pasien stroke nonhemoragik dengan derajat berat (NIHSS 15-25) didapatkan empat pasien, pada pasien non-hemoragik dengan derajat sedang (NHISS 5-14) didapatkan 53 pasien, dan pada pasien stroke nonhemoragik dengan derajat ringan (NHISS <5) didapatkan 41 pasien. ${ }^{9}$

Penelitian yang dilakukan oleh DeGraba et al. pada 127 pasien dengan stroke iskemik di unit gawat darurat National Naval Medical Center (NNMC). Sebanyak 86 pasien laki-laki dan 41 pasien perempuan dengan defisit fokal yang menetap dilakukan penilaian awal NIHSS skor menunjukkan skor rerata 7,1. Secara keseluruhan, terdapat progresifitas defisit neurologik dalam 40 kasus yang diteliti (31,5\%), dengan usia rata-rata penderita stroke yaitu 66,5 tahun. ${ }^{10}$

Hasil yang berbeda didapatkan pada penelitian yang dilakukan oleh Indiyarti di RSUPPN Dr. Cipto Mangunkusomo Jakarta yaitu defisit neurologik yang dialami penderita stroke hemoragik derajat berat (NIHSS>15) sekitar 25\% sedangkan pada penderita stroke non-hemoragik sebagian besar defisit neurologik dengan derajat sedang (NIHSS 4-15) sekitar 30\%. ${ }^{11}$

Berdasarkan hasil pembahasan diatas didapatkan bahwa derajat defisit neurologik bervariasi dalam setiap penelitian.

\section{SIMPULAN DAN SARAN}

Dari hasil penelitian dan bahasan dapat disimpulkan bahwa pada pemeriksaan NIHSS derajat neurologis ringan penderita stroke hemoragik lebih banyak daripada penderita stroke non hemoragik, untuk derajat neurologis sedang sama banyak, dan untuk derajat neurologis berat 
penderita stroke non hemoragik lebih banyak.

\section{DAFTAR PUSTAKA}

1. Gofir A. Manajemen Stroke. Yogyakarta: Pustaka Cendekia Press, 2011; p. 1745.

2. Immanuel S, Utami L. Petanda biokimia stroke. Maj Kedokt Indon. 2009;59:538-9.

3. Wirawan RP. Rehabilitasi stroke pada pelayanan kesehatan primer. Maj Kedokt Indon. 2009;59:61-2.

4. Amarenco P, Bogousslavsky J, Caplan LR, Donnan GA, MG Hennerici. Classification of stroke subtypes. Cerebrovasc Dis. 2009;27:493-501.

5. Martono H, Kuswardani T. Stroke dan penatalaksanaannya oleh internis: An overview. In: Sudoyo W Aru, et al, editors. Buku Ajar Ilmu Penyakit Dalam Jilid III (4th ed). Jakarta: UI University, 2006; p. 1411.

6. Harsono, editor. Buku Ajar Neurologi Klinis (5th ed). Yogyakarta: GM
University, 1996; p. 61-9.

7. NIH stroke scale International. Avaible from : www.nihstrokescale.org

8. Siswonoto S. Hubungan kadar malondialdehid plasma dengan keluaran klinis stroke iskemik [Tesis]. Semarang: Program Pendidikan Dokter Spesialis I Ilmu Penyakit Saraf Universitas Diponegoro; 2008.

9. DeGraba TJ, et al. Progression in acute stroke value of the initial NIH Stroke Scale Score on patient stratification in future trials. Available from: http://stroke.ahajournals.org/content/3 0/6/1208

10. Altafi D, Khotbesara M H, Khotbesara M H, Bagheri A. A comparative study of NIHSS between ischemic stroke patients with and without risk factors. Available from: www.tjeas.com

11. Riani I. Perbandingan kadar gula darah sewaktu pada kedua jenis stroke. J Kedokteran Trisakti. 2002;23(4):11521. 